da SILVA, M; OLIVEIRA, L. S.; RADAELLI, J. C.; JUNIOR, A. W.; POSSENTI, J. C. Germinação de sementes de Punica granatum de acordo com temperatura e período de armazenamento. Pesquisa Aplicada \& Agrotecnologia, Guarapuava-PR, v.12, n.01, p.119-123, Jan-Abr., 2019. DOI: 10.5935/PAeT.V12.N1.13

\section{Nota Técnica}

\section{Abstract}

The aim of the study was to evaluate the germination of $P$. granatum seeds after storage under different temperatures. The experiment was performed at Universidade Tecnológica Federal do Paraná - UTFPR

\title{
Germination of Punica granatum seed according to temperature and storage period
}

\author{
Marcieli da Silva ${ }^{1}$ \\ Lucas Silva Oliveira ${ }^{2}$ \\ J uliana Cristina Radaelli ${ }^{3}$ \\ Américo Wagner J uni or ${ }^{4}$ \\ J ean Carlo Possenti ${ }^{5}$
} - Campus Dois Vizinhos. The seeds were stored in sealed glass jars under temperatures of $5^{\circ} \mathrm{C}, 10^{\circ} \mathrm{C}$ e $25^{\circ} \mathrm{C}$, 글 por $0,30,60,90,120,150,180,210$ and 240 days. After each period, the seeds were sowed in Gerbox ${ }^{\circledR}$ boxes kept at $25^{\circ} \mathrm{C}$. A completely randomized design was used, in a factorial $3 \times 9$ (temperature $\times$ period of storage), तิ with four repetitions of 100 seeds each. After 60 days of implementation, percentage of germinated seeds, GSI and AGT, were evaluated. The data was transformed and submitted to variance analysis $(\mathrm{p} \leq 0,05)$ and Duncan's test. Seeds of $P$. granatum can be stored at the temperature of $5^{\circ} \mathrm{C}$ for 240 days.

Key words: punicaceae, pomegranate, seeds.

\section{Germinação de sementes de Punica granatum de acordo com temperatura e período de armazenamento}

\section{Resumo}

O objetivo do trabalho foi avaliar a germinação das sementes de P. granatum após o armazenamento em diferentes temperaturas. O experimento foi realizado na UTFPR - Câmpus Dois Vizinhos. As sementes foram armazenadas em frascos de vidro lacrados. Logo, procedeu-se o armazenamento nas temperaturas de $5^{\circ} \mathrm{C}, 10^{\circ} \mathrm{Ce} 25^{\circ} \mathrm{C}$, por $0,30,60,90,120,150,180,210$ e 240 dias. Decorrido cada período procedeu-se semeadura em caixas Gerbox ${ }^{\circledR}$ mantidas a $25^{\circ} \mathrm{C}$. O delineamento utilizado foi DIC, em fatorial $3 \times 9$ (temperatura de armazenamento $x$ tempo), com quatro repetições de 100 sementes cada. Após 60 dias da implantação do experimento avaliou-se o percentual de sementes germinadas, IVG e TMG. Os dados das variáveis foram transformados e submetidos à análise de variância $(\mathrm{p} \leq 0,05)$ e ao teste de Duncan. As sementes de $P$. granatum podem ser armazenadas a temperatura de $5^{\circ} \mathrm{C}$ por período de 240 dias.

Palavras-chave: punicaceae, romã, semente.

\section{Germinación de semillas de Punica granatum de acuerdo con temperatura y período de almacenamiento}

\section{Resumen}

El objetivo del trabajo fue evaluar la germinación de las semillas de P. granatum después del almacenamiento en diferentes temperaturas. El experimento fue realizado en la UTFPR - Cámpus Dois Vizinhos. Las semillas fueron almacenadas en frascos de vidrio sellados. Por lo tanto, se procedió al almacenamiento a temperaturas de $5^{\circ} \mathrm{C}, 10^{\circ} \mathrm{C}$ y $25^{\circ} \mathrm{C}$, por $0,30,60,90,120,150,180,210$ y 240 días. Después de cada período se procedió a la siembra en cajas Gerbox mantenidas a $25^{\circ} \mathrm{C}$. El delineamiento utilizado fue DIC, en factorial $3 \times 9$ (temperatura de almacenamiento $\times$ tiempo), con cuatro repeticiones de 100 semillas cada una. Después de 60 días de la implantación del experimento se evaluó el porcentaje de semillas germinadas,

\section{Received at: 12/12/2017_ Accepted for publication at: 28/05/2018}

1,3 Doutorando (a) do Programa de Pós-Graduação em Agronomia - Departamento Produção Vegetal Universidade Tecnológica Federal do Paraná- Campus Pato Branco-PR/ Brasil. CEP: 85503-390. E-mail: marcielidasilva@hotmail.com; julianaradaelli@gmail.com

2 Graduando (a) no curso de agronomia - Departamento de Fisiologia Vegetal - Universidade Tecnológica Federal do Paraná - Campus Dois Vizinhos-PR/Brasil. CEP: 85660-000. E-mail: lukas201190@hotmail.com 4 Professor, Bolsista produtividade - Departamento Produção Vegetal - Universidade Tecnológica Federal do Paraná- Campus Dois Vizinhos-PR/ Brasil. CEP: 85503-390. E-mail: americowagner@utfpr.edu.br

5 Professor do Programa de Pós-Graduação em Agronomia - Departamento Produção Vegetal - Universidade Tecnológica Federal do Paraná - Campus Dois Vizinhos-PR/ Brasil. CEP: 85503-390. E-mail: jpossenti@utfpr.edu.br

Applied Research E Agrotechnology $\quad$ v.12, n.1, jan/apr. (2019)

(On line) e-ISSN 1984-7548 
índice de velocidad de germinación (IVG) y tiempo medio de germinación (TMG). Los datos de las variables fueron transformados y sometidos al análisis de varianza $(\mathrm{p} \leq 0,05)$ y prueba de Duncan. Las semillas de $\mathrm{P}$. granatum se pueden almacenar a una temperatura de $5^{\circ} \mathrm{C}$ durante un período de 240 días.

Palabras clave: punicaceae, román, semilla.

\section{Introduction}

Punica granatum L., commonly known as pomegranate (JARDINI \& FILHO 2007), belongs to the Punicaceae family, being a woody and branched shrub native to the region from Iran to the Himalayas, Northwest India. Its cultivation is wide in all the Mediterranean region of Asia, America, Africa and Europe (LORENZI \& SOUZA 2001, FERREIRA 2009).

It is cultivated on a large scale in regions of tropical and subtropical climates, being used both in fruit growing, in ornamentation and also as a medicinal plant (JARDINI \& FILHO 2007).

Among the medicinal properties attributed to this plant, phytochemical analysis shows the presence of alkaloids and gallic tannins in the bark of the stem and fruits. In the leaves and seeds the presence of fatty acids, mainly, Punic acid (SOUSA et al. 1991) was verified. Due to the diverse functional properties and nutraceuticals, the fruit has gained great prominence worldwide (SUMNER et al. 2005). According to GARCIA (1992), the species has antibacterial and anti-inflammatory properties, MENEZES et al. (2008) reported it as astringent, hemostatic, antidiabetic, anthelmintic, antidiarrheal, antiseptic and antiviral. Despite this, it is still very little used in commercial orchards in Brazil, which makes it an alternative for use by producers eager for news.

To solve this situation and make it attractive, first is necessary to carry out the marketing with the population of the advantages that its consumption brings to health and the creation of commercial orchards.

The germination of these seeds is uneven and low in percentage, although there are no studies on storage forms that maintain their physiological quality (PIOTTO et al. 2003).

Studies on the physiological quality of seeds are of most importance, due to many degenerative changes which may occur, of physiological, chemical and physical origin, which occur after maturity, and are closely linked to the reduction or even loss of seed vigor. In this way, storage overlaps as an essential practice to conserve the physiological quality of the seed (AZEVEDO et al. 2003), and to reduce the speed of deterioration, since the improvement of the quality is not possible, even in ideal conditions (VILLELA e PEREZ, 2004).

Thus, seed storage becomes a safe and economical way of conserving plant genetic diversity, being efficient when it maintains the physiological potential for as long as possible, which depends on the behaviour of the seed along storage (COSTA 2009) and the condition in which it is.

The most relevant factors for conservation of seed viability are the environmental storage conditions, such as temperature and water content. To maintain the quality of orthodox seeds, low relative humidity and low temperature are required, thus the metabolic activity of the embryo reduces, consequently decreasing the deterioration (CARVALHO \& NAKAGAWA 2012, LIMA et al. 2014, SMANIOTTO et al. 2014).

Due to the lack of information about this species, the objective of this work was to evaluate the germinative process of $P$. granatum seeds after storage at different temperatures.

\section{Materials and methods}

The experiment was carried out at the Laboratory of Plant Physiology, at the Universidade Tecnológica Federal do Paraná - Campus Dois Vizinhos.

Seeds of mature fruits of $P$. granatum were used, from the orchard of the respective institution. The seeds were extracted manually, then lime was added to facilitate the removal of the aril by friction in a fine mesh sieve, with successive washing in running water. The seeds were then kept in the shade for 24 hours at room temperature to remove the excess of moisture.

After this process, the seeds were separated into batches of 100 units and stored in sealed glass jars of approximately $20 \mathrm{~mL}$. Therefore, incubated at temperatures of $5^{\circ} \mathrm{C}, 10^{\circ} \mathrm{C}$ and $25^{\circ} \mathrm{C}$. Storage periods were $0,30,60,90,120,150,180,210$ and 240 days.

After each period, seeds were sowed in Gerbox ${ }^{\circledR}$ boxes with lid, containing Germtest paper moistened as a substrate. For the germination tests, the boxes were placed in a B.O.D. at $25^{\circ} \mathrm{C}$.

The design was completely randomized, in factorial $3 \times 9$ (storage temperature $x$ time), with four 
Germinação de sementes de Punica granatum... Germination of Punica granatum seed... Germinación de semillas de Punica granatum...

replicates of 100 seeds each.

The counting was carried out daily, being considered as germinated the seeds that had visible radicle. After 60 days of the implantation of the experiment the percentage of germinated seeds, germination speed index (GSI) and average germination time (AGT) were evaluated. The data of the evaluated variables were previously submitted to the normality test of Lilliefors, confirming the need to transform all data. The transformation was carried out using $\sqrt{ } x+1$ for GSI and AGT and sine arc $\sqrt{ } x 1$ for germination. They were then submitted to analysis of variance $(p \leq 0.05)$ and Duncan's test for comparison of means using SANEST ${ }^{\circledR}$ software.

\section{Results and discussion}

According to the analysis, there was a significant interaction between temperature and time in all variables analysed (Tables 1,2 and 3).

For germination, the highest averages were obtained at 30, 60 and 210 days using a storage temperature of $5^{\circ} \mathrm{C}$. At $10^{\circ} \mathrm{C}$ at 60,90 and 210 days, and at $25^{\circ} \mathrm{C}$ at 60 and 90 days, with the latter reaching $50 \%$ germination (Table 1 ).

It should be noted in these data from Table 1, that in both storage temperatures, the seeds, despite varying their germination, were still viable, which may be associated with the use of the sealed glass jars to preserve them, avoiding exchanges with the environment.

The moisture content of the seeds stored in permeable packages is influenced more by the atmospheric conditions of the storage site, different from the impermeable ones that do not allow water vapour exchanges of the seeds with the medium in which they are stored and of the semipermeable ones that provide better resistance (SILVA et al. 2010). However, it is not possible to determine the effect of water permeability on the permeability of the soil.

The packaging that presents greater permeability and consequently greater exchange of humidity of the environment with the seeds, propitiates greater activity of microorganisms, insects and entails greater consumption of reserves, reducing the quality of the seeds (CONDÉ e GARCIA, 1984). However, the waterproof packaging maintains the physiological quality of the seeds for longer storage periods, since it reduces the availability of oxygen reducing the loss of dry matter mass, as well as insect proliferation (BAUDET, 2003).

Comparing the germinations obtained in each period, the highest averages were found at 30, 150 and 240 days at $5^{\circ} \mathrm{C}$, and at 180 and 210 days, this did not differ statistically from $10^{\circ} \mathrm{C}$. However, at 120 days there was similarity in superiority at $5^{\circ} \mathrm{C}$ and $25^{\circ} \mathrm{C}$ and at 90 days at $10^{\circ} \mathrm{C}$ and $25^{\circ} \mathrm{C}$. At 60 days, both temperatures did not differ statistically from each other (Table 1 ).

Table 1: Germination of $P$. granatum seeds stored under different temperatures and storage time.

\begin{tabular}{|c|c|c|c|c|}
\hline & \multicolumn{4}{|c|}{ Temperatures } \\
\hline \multirow{2}{*}{$\frac{\text { Time }}{0}$} & \multirow{2}{*}{$\frac{5^{\circ} \mathbf{C}}{20,99 d}$} & $10^{\circ} \mathrm{C}$ & \multicolumn{2}{|c|}{$25^{\circ} \mathrm{C}$} \\
\hline & & A $20,99 \mathrm{bcd}$ & A 20,99 c & A \\
\hline 30 & $41,09 \mathrm{abc}$ & A 27,24 bc & В $27,21 \mathrm{~b}$ & B \\
\hline 60 & $48,48 \mathrm{a}$ & A 39,99 a & A 50,23 a & A \\
\hline 90 & $17,99 \mathrm{~d}$ & B 46,49 a & A 50,74 a & A \\
\hline 120 & $34,05 \mathrm{bc}$ & A $17,21 \mathrm{~d}$ & В $29,79 \mathrm{~b}$ & A \\
\hline 150 & $35,86 \mathrm{bc}$ & A $18,43 \mathrm{~cd}$ & B 18,16 c & B \\
\hline 180 & $30,89 \mathrm{c}$ & A $28,23 \mathrm{~b}$ & A 7,94 d & B \\
\hline 210 & $43,18 \mathrm{ab}$ & A 44,68 a & A 21,99 bc & B \\
\hline 240 & $36,07 \mathrm{bc}$ & A 26,34 bc & B 15,46 c & $\mathrm{C}$ \\
\hline CV $(\%$ & & 12,27 & & \\
\hline
\end{tabular}

*Averages with different letters, lowercase in the column and uppercase in the row, differ significantly at a 5\% level of probability by Duncan's test.

However, the percentage of germination remained low throughout the study. LOPES et al. (2001), working with pomegranate seeds, analyzed five fermentation periods in relation to the two conditions (with and without drying), concluding that they had characteristics of dormancy or drying sensitivity characteristics of recalcitrant seeds, which may have influenced these values obtained in the present study (Table 1 ).

The temperature variations considerably compromise germination speed, percentage and uniformity, and it is important to identify the most efficient combination between germination percentage and germination speed (MARCOS FILHO, 2005).

The germination speed index did not show significant differences from zero at 60 days in the three temperature conditions (Table 2). In the other periods, considering the 120,150, 180, 210 and 240 days, the highest IVGs were with seeds kept at $5^{\circ} \mathrm{C}$, which was statistically similar in the last two periods with the condition of $10^{\circ} \mathrm{C}$ (Table 2). Already at 90 days the highest averages were with seeds kept at $10^{\circ} \mathrm{C}$ and $25^{\circ} \mathrm{C}$. The higher superiority obtained at $5^{\circ} \mathrm{C}$ may be due to the lower metabolic activity provided to the 
da Silva et al. (2019)

seed, thus favouring the conservation of the reserves, which are useful to allow greater vigour.

The average germination time of the pomegranate seeds stored at $5^{\circ} \mathrm{C}$ was lower at 0,60 , 90,180 and 240 days, at $10^{\circ} \mathrm{C}$ at $0,30,60,120,180$ and 240 days and at $5^{\circ} \mathrm{C}$ the highest AGT was obtained at 60 and 180 days, with $10^{\circ} \mathrm{C}$ at 60,90 and 180 days, and at $25^{\circ} \mathrm{C}$ only at 60 days (Table 2 ). The results obtained with GSI at $25^{\circ} \mathrm{C}$ partially confirm the hypothesis related to the possible higher amount of reserve in seeds kept at the lowest temperature, since it was only possible to maintain the highest vigour until 60 days, since from this period the same Consume their reserves to maintain the seeds allowing the least vigour.

Table 2: Germination of $P$. granatum seeds stored under different temperatures and storage time.

\begin{tabular}{|c|c|c|c|c|}
\hline \multirow{3}{*}{$\begin{array}{c}\text { Time } \\
0\end{array}$} & \multicolumn{4}{|c|}{ Temperatures } \\
\hline & \multirow{2}{*}{$\frac{5^{\circ} \mathrm{C}}{1,28 \mathrm{~b}}$} & \multirow{2}{*}{$\frac{10^{\circ} \mathrm{C}}{\mathrm{A} 1,28 \mathrm{bcd}}$} & \multicolumn{2}{|c|}{$25^{\circ} \mathrm{C}$} \\
\hline & & & A $1,28 \mathrm{~b}$ & A \\
\hline 30 & $1,43 \mathrm{~b}$ & A $1,23 \mathrm{~cd}$ & A $1,27 b$ & A \\
\hline 60 & $2,44 \mathrm{a}$ & A 1,96 a & A 2,31 a & A \\
\hline 90 & $0,72 \mathrm{c}$ & B 1,72 abc & A $1,46 b$ & A \\
\hline 120 & $1,27 \mathrm{~b}$ & A 0,64 e & B $0,59 \mathrm{~cd}$ & B \\
\hline 150 & $1,18 \mathrm{~b}$ & A 0,57 e & B $0,40 \mathrm{~cd}$ & B \\
\hline 180 & $2,22 \mathrm{a}$ & A $1,65 a b c$ & B $0,27 \mathrm{~d}$ & C \\
\hline 210 & $1,35 \mathrm{~b}$ & A $1,84 \mathrm{ab}$ & A 0,62 c & B \\
\hline 240 & $1,28 \mathrm{~b}$ & A $1,11 \mathrm{~d}$ & A $0,44 \mathrm{~cd}$ & B \\
\hline CV $(\%)$ & & 10,02 & & \\
\hline
\end{tabular}

During storage, temperature and relative humidity are decisive in the process of loss of seed viability, also influencing the quality of the product and by-products (MALAKER et al. 2008).

According to a study conducted by ARAÚJO NETO et al. (2005) the storage of Acacia polyphylla DC seeds. In an environment without temperature control and air humidity was inefficient to maintain their physiological quality. However, when stored in impermeable packaging and in a cold room, the seeds remained viable for two years. Similar results were obtained by BARBEDO et al. (2002) with
Caesalpinia echinata Lam seeds that lost viability when stored under normal ambient conditions (22 $\pm 7^{\circ} \mathrm{C}$ ) in less than three months. On the other hand, under low temperature (cold chamber at $7 \pm 1^{\circ} \mathrm{C}$ ) the viability was maintained for up to 18 months, with germination higher than $80 \%$.

In those maintained at $25^{\circ} \mathrm{C}$, the results only stood out at 0 and 30 days (Table 3 ). Comparing storage temperatures, it can be seen that the use of the 5 and $10^{\circ} \mathrm{C}$ conditions showed the best averages, since they maintained less germination time up to 240 days, except for 180 days at $10^{\circ} \mathrm{C}$ (Table 3). This may be related to the need of pomegranate to the stratification to break its dormancy, thus allowing the shorter times for germination, as already verified by RAWAT et al. (2010).

Table 3: Average germination time (AGT) of $P$. granatum seeds stored under different temperatures and storage time.

\begin{tabular}{|c|c|c|c|c|}
\hline \multirow{3}{*}{$\frac{\text { Time }}{0}$} & \multicolumn{4}{|c|}{ Temperatures } \\
\hline & $5^{\circ} \mathrm{C}$ & $10^{\circ} \mathrm{C}$ & $25^{\circ} \mathrm{C}$ & \\
\hline & $21,54 \mathrm{ab}$ & A 21,54 a & A $21,54 \mathrm{a}$ & A \\
\hline 30 & $26,79 \mathrm{bc}$ & A $25,47 \mathrm{ab}$ & A 23,26 a & A \\
\hline 60 & $23,11 \mathrm{abc}$ & A $25,23 \mathrm{ab}$ & A $26,67 \mathrm{~b}$ & A \\
\hline 90 & $23,58 a b c$ & A 28,49 bc & A $36,36 \mathrm{~cd}$ & B \\
\hline 120 & $27,71 \mathrm{c}$ & A $25,67 \mathrm{ab}$ & A $43,21 \mathrm{~d}$ & B \\
\hline 150 & $30,71 \mathrm{~d}$ & A 33,36 c & A $45,58 d$ & B \\
\hline 180 & $14,65 \mathrm{a}$ & A 21,68 a & B 31,89 bc & C \\
\hline 210 & $32,61 \mathrm{~d}$ & A 32,78 c & A $46,68 d$ & B \\
\hline 240 & $23,67 \mathrm{abc}$ & A $24,31 \mathrm{ab}$ & A $35,45 \mathrm{~cd}$ & B \\
\hline
\end{tabular}

CV (\%) $\quad 6,76$

${ }^{*}$ Averages with different letters, lowercase in the column and uppercase in the row, differ significantly at a 5\% level of probability by Duncan's test.

\section{Conclusion}

The seeds of $P$. granatum can be stored at the temperature of $5 \mathrm{oC}$ under the period of 240 days. However, further studies are needed to increase the number of germinated seeds. 
Germinação de sementes de Punica granatum... Germination of Punica granatum seed... Germinación de semillas de Punica granatum... p. $119-123$

\section{References}

ARAÚJO NETO, J.C.; AGUIAR, I.V.; FERREIRA, V.M.; RODRIGUES, T.J.D. 2005. Armazenamento e requerimento fotoblástico de sementes de Acacia polyphylla DC. Revista Brasileira de Sementes, Pelotas, v.27, n.1, p.115-124.

AZEVEDO, M.R.Q.A.; GOUVEIA, J.P.G.; TROVÃO, D.M.M.; QUEIROGA, V.P. 2003. Influência das embalagens e condições de armazenamento no vigor de sementes de gergelim. Revista Brasileira de Engenharia Agrícola e Ambiental, Campina Grande-PB, v. 7, n. 3, p. 519-524.

BARBEDO, C.J.; BILIA, D.A.C.; FIGUEIREDO, R.R.CL. 2002. Tolerância à dessecação e armazenamento de sementes de Caesalpinia echinata Lam (pau-brasil), espécie da Mata Atlântica. Revista Brasileira de Botânica, São Paulo, v.25, n.4, p.431-439.

BAUDET, L.M.L. 2003. Armazenamento de sementes. In: PESKE, S.T.; ROSENTAL, M.D.; ROTA, G.R. (ed.). Sementes: fundamentos científicos e tecnológicos, Pelotas: Ed. Universitária - UFPel, p.370-418.

CARVALHO, N.M.; NAKAGAWA, J. 2012. Sementes: ciência, tecnologia e produção. Jaboticabal: FUNEP, 590p. CONDÉ, A.R.; GARCIA, J. 1984. Armazenamento e embalagem de sementes de forrageira. Informe Agropecuário, Belo Horizonte, v.10, n.111, p.44-49.

COSTA, C. J. 2009. Armazenamento e conservação de sementes de espécies do Cerrado. Planaltina-DF: Embrapa Cerrados, 30p.

FERREIRA, A.B.H. Novo dicionário Aurélio da língua portuguesa. 2009. 4 ed. São Paulo: Instituto Adolfo Lutz. 2120p.

GARCIA, A.A. 1992. La terapeutica com plantas medicinales: fitoterapia - vademecum de prescripcion, Bilbao: cita Publicaciones, 175 p.

JARDINI, F.A.; FILHO, J.M. 2007. Avaliação da atividade antioxidante em diferentes extratos da polpa e sementes da romã (Punica granatum, L.). Revista Ciência Farmaceutica Básica Aplicada. São Paulo, vol. 43, n. 1. p. $137-147$.

LIMA, D.C.; DUTRA, A.S.; CAMILO, J.M. 2014. Physiological quality of sesame seeds during storage. Revista Ciência Agronômica, Fortaleza, v.45, n.1, p.138-145.

LOPES, K. P.; BRUNO, R. L. A.; BRUNO, G. B.; AZEREDO, G. A. 2001. Comportamento de sementes de romã (Punica granatum L.) submetidas à fermentação e secagem. Revista Brasileira de Fruticultura, Jaboticabal, v. 23, n. 2, p. 369-372.

LORENZI, H.; SOUZA, H.M. 2001. Plantas ornamentais no Brasil - arbustivas, herbáceas e trepadeiras. 3.ed. Nova Odessa: Plantarum, 1088p.

MALAKER, P.K.; MIAN, I.H.; BHUIYAN, K.A.; AKANDA, A.M.; REZA, M.M.A. 2008. Effect of storage containers and time on seed quality of wheat. Bangladesh Journal of Agricultural Research, Bangladesh, v.33, p.469-477.

MARCOS FILHO, J. 2005. Fisiologia de sementes de plantas cultivadas. Piracicaba: FEALQ, 495 p.

MENEZES, S. M. S.; PINTO, D. M.; CORDEIRO, L. N. 2008. Atividades biológicas in vitro e in vivo de Punica granatum L. (romã). Revista Brasileira de Medicina. São Paulo, v. 65, n. 11, p. 388-391.

PIOTTO, B.; et al., 2003. Fact sheets on the propagation of mediterranean trees and shrubs from seed. In: PIOTTO, B.; DI NOI, A. (Ed.). Seed propagation of mediterranean trees and shrubs. Rome: Agency for the Protection of the Environment and for Technical Services, p.11-51

RAWAT, J. M. S.; TOMAR, Y. K.; RAWAT, V. 2010. Effect of stratification on seed germination and seedling performance of wild pomegranate. Journal of American Science, New York. v. 6, n. 5, p. 97-99.

SILVA, L. M.M.; MATA, M.E.R.M.C.; DUARTE, M.E.M. 2015. Teor de água limite para crioconservação de sementes de romã (Punica granatum L.). Engenharia Agrícola Jaboticabal, Jaboticabal. v. 35, n.2, p.313-321.

SILVA, F. S. da; PORTO, A. G.; PASCUALI, L. C.; SILVA, F. T. C. da. 2010. Viabilidade do armazenamento de sementes em diferentes embalagens para pequenas propriedades rurais. Revista de Ciências Agroambientais, Alta Floresta. v.8, p.45-56.

SMANIOTTO, T.A.S.; RESENDE, O.; MARÇAL, K.A.F.; OLIVEIRA, D.E.C.; SIMON, G.A. 2014. Qualidade fisiológica das sementes de soja armazenadas em diferentes condições. Revista Brasileira de Engenharia Agrícola Ambiental, Campina Grande. v.18, n.4, p.446-453.

SOUSA, M.P.; MATOS, M.E.O.; MATOS, F.J.A. 1991. Constituintes químicos de plantas medicinais brasileiras. Fortaleza: Imprensa Universitária/UFC, 416p. 